Paidéia, 2005, 15(32), 397-407

\title{
O DESENVOLVIMENTO PROFISSIONAL DE PROFESSORES DAS SÉRIES INICIAIS DO ENSINO FUNDAMENTAL ${ }^{1}$
}

\author{
Cilene Ribeiro de Sá Leite Chakur ${ }^{2}$ \\ FCL - Universidade Estadual Paulista de Araraquara
}

\begin{abstract}
Resumo: Pesquisa anterior mostrou que a profissionalidade de professores de $5^{\mathrm{a}}$ a $8^{\mathrm{a}}$ séries se desenvolve em diferentes níveis e que há certos padrões nas reações dos professores diante de conflitos do cotidiano escolar. O presente estudo investigou se existiriam diferenças entre professores quanto aos níveis alcançados. Foram entrevistadas 14 professoras de $1^{\text {a a }} 4^{\text {a }}$ de uma escola pública paulista sobre histórias hipotéticas, cada qual contendo problema a ser julgado/solucionado; a análise obedeceu a critérios baseados no referencial piagetiano. Os resultados indicaram que os depoimentos dos professores de $1^{\mathrm{a}}$ a $4^{\mathrm{a}}$ séries se distribuem pelos mesmos níveis encontrados anteriormente e que são as mesmas as formas de reação ao conflito. Conclui-se que o desenvolvimento profissional docente ocorre em uma seqüência de níveis hierárquicos e, para que os esquemas profissionais progridam e se aperfeiçoem, é fundamental a tomada de consciência dos obstáculos enfrentados, primeiro passo para a sua solução.
\end{abstract}

Palavras-chave: profissionalidade docente; desenvolvimento profissional do professor; níveis de aquisição da profissionalidade docente.

\section{THE PROFESSIONAL DEVELOPMENT OF TEACHERS FROM THE INITIAL GRADES OF PRIMARY SCHOOL}

\begin{abstract}
A previous research showed that the professionality of teacher's from $5^{\text {th }}$ to $8^{\text {th }}$ grades is developed in different levels and that there are certain patterns in the teachers' reactions up against daily school conflicts. This present study intended to verify if there would be differences in the professionality levels between the teachers. Fourteen teachers from $1^{\text {st }}$ to $4^{\text {th }}$ grades of a public school in a city from São Paulo State were interviewed about hypothetical stories, each one containing a problem to be judged/solved; the analysis complied with piagetian criteria. The results indicated that these teachers' depositions are distributed by the same levels previously found and the reaction ways to the conflict are just the same. It was conclude that the teacher's professional development occurs in a sequence of hierarchical levels and in order to make the professional schemes progress and improve it is fundamental to be aware of the presented obstacles, first step for its solution.
\end{abstract}

Key words: teacher's professionality; teacher's professional development; acquisition levels of the teacher's professionality.

Introdução: Há pesquisas investigando o professor e programas de intervenção, incluindo pesquisa-ação colaborativa ${ }^{3}$, focalizadas em professores dos dois ciclos $\left(1^{\mathrm{a}}\right.$ a $4^{\mathrm{a}}$ e $5^{\mathrm{a}}$ a $\left.8^{\mathrm{a}}\right)$ de duas escolas públicas ${ }^{4}$.

\footnotetext{
${ }^{1}$ Artigo recebido em 08/08/2005 e aceito para publicação em 16/11/2005. ${ }^{2}$ Endereço para correspondência: Cilene Ribeiro de Sá Leite Chakur, Rua Camilo Biffi, 189 - Cidade Jardim, - Araraquara - SP, CEP: 14805-171, E-mail: chakur@fclar.unesp.br

3 O projeto com professores dos dois ciclos teve financiamento da FAPESP e do CNPq.

${ }^{4}$ A referência, neste caso, centraliza-se na cidade de Araraquara.
}

Projetos anteriores têm indicado que os professores, ano após ano, apresentam progressos nos âmbitos da prática pedagógica, da autonomia de trabalho e na própria identidade profissional. Estes dados levaram a propor uma pesquisa voltada especificamente para a questão do desenvolvimento profissional docente.

O professor, sua identidade e trabalho têm sido investigados sob o chamado paradigma do pensamento do professor (Imbernón, 1994; Shavelson \& Stern, 1981; Zabalza, 1994), que tem defendido o 
ensino como prática reflexiva e valorizado os saberes obtidos na própria prática pelo docente (Giovanni, 1994; Marcelo García, 1992; Nóvoa, 1992, 1994, 1995; Pérez Gómez, 1992; Schön, 1992a, 1992b; Zeichner, 1992, 1993).

A literatura que focaliza o desenvolvimento profissional docente segue essa tendência, tomando o professor como prático reflexivo (Nóvoa, 1994; 1995; Pérez Gómez, 1992) e apresentando descrições sobre sua história profissional, no mais das vezes conforme o critério do desenrolar cronológico. Contudo, alguns estudos que se situam dentro da abordagem do pensamento do professor mostram lacunas e indefinições no tratamento da profissionalidade docente e exaltações pouco fundadas da capacidade autônoma dele de decidir sobre a própria prática. Nota-se, por exemplo, que não há consenso na conceituação de prática reflexiva, nem de reflexão (Contreras, 2002; Marcelo García, 1992; Zeichner, 1993); assim também, parecem existir falhas na caracterização do processo de desenvolvimento profissional do professor e na definição do mecanismo regulador responsável pelo controle dos "desvios de rota” desse processo.

Os trabalhos de Huberman (1995) e Cavaco (1995), já bastante conhecidos como estudos que retratam o desenvolvimento profissional de professores, têm se constituído em marcos de referência sobre o tema, tratando a idéia de que existem certas tendências gerais no ciclo de vida dos professores, que comporta uma seqüência de fases cuja ordem obedece ao tempo de carreira.

Assim, segundo Huberman (1995), o professor passa por uma fase inicial de sobrevivência e descoberta, com a entrada na carreira, que traz o sentimento de choque da realidade, mas implica em explorações e experimentações; em seguida, vem a do comprometimento definitivo ou estabilização, que ocorre entre 4 e 6 anos de carreira e favorece sentimentos ao mesmo tempo de independência e de pertença a um corpo profissional; a fase de diversificação, entre 7 e 25 anos, revela percursos individuais que vão desde a rotina até a crise existencial; dos 25 aos 35 anos caracteriza-se o aparecimento da serenidade $e$ distanciamento afetivo, ou do conservantismo; e a fase do desinvestimento (sereno ou amargo) referese à época da aposentadoria, entre 35 e 40 anos de carreira.
Na seqüência de fases acima, a carreira docente pode tomar diferentes percursos, alguns "harmoniosos”, outros “problemáticos”. Huberman (1995) e Cavaco (1995) consideram que essa seqüência não é universal, nem seu transcurso independente de condições sociais e do período histórico. Para eles, cada etapa prepara a seguinte, mas sem chegar a determinar a ordem seguida. Como afirma Cavaco (1995), a possibilidade de se identificarem traços seqüenciais, perfis de desenvolvimento vocacional, não se atrela à "existência de indicadores normativos que regulem a direcção, o ritmo, as finalidades e as modalidades do processo de evolução profissional”(p.179)..

Outro estudo com visão e tratamento diferentes do tema em questão é apresentado por Levin e Ammon (1992), que,numa pesquisa longitudinal, cobrindo três momentos, acompanharam por cinco anos o desenvolvimento do pensamento pedagógico de quatro professores da escola elementar: o primeiro momento, quando começaram o programa de educação em pré-serviço; o segundo, quando se graduaram, dois anos mais tarde; e o terceiro, durante seu terceiro ano de ensino efetivo; como objetivo completar, o estudo pretendeu avaliar um programa de educação de professores implementado na Universidade da Califórnia, baseado na teoria piagetiana.

Os dados coletados em entrevista clínica e observações, nos três momentos da pesquisa, foram analisados segundo o modelo dos níveis de concepção pedagógica, que supõe que as compreensões mais avançadas evoluem de outras primitivas, seguindo uma seqüência invariante. Segundo o modelo, há cinco níveis qualitativamente diferentes de concepção pedagógica, dispostos em quatro áreas: comportamento, desenvolvimento, aprendizagem e ensino. Os níveis nas áreas de aprendizagem e ensino (Levin \& Ammon, 1992), seriam:

1. Empirismo Ingênuo - em que a aprendizagem deriva da experiência e ensinar é mostrar e expor verbalmente. 2. Behaviorismo Cotidiano - em que a aprendizagem provém de fazer (praticar) e o ensino é modelagem e reforçamento.3. Construtivismo Global - quando a aprendizagem provém da exploração e o ensino é fornecer experiência participativa. 4. Construtivismo Diferenciado - a aprendizagem deriva da ação de dar sentido e o ensino é guiar o pensamento dentro dos domínios. 5. Construtivismo Integra- 
do - a aprendizagem deriva da solução de problema e o ensino é guiar o pensamento através dos domínios.

Segundo os autores, os níveis inferiores se caracterizam pela unidimensionalidade, que progride em direção à multidimensionalidade própria dos superiores, quando, então, as explicações dos professores apresentam múltiplos fatores. Nos níveis 4 e 5, eles tendem a dar exemplos específicos de seu pensamento sobre o ensino e a aprendizagem e a usar exemplos de diferentes áreas, o que ilustraria, o construtivismo diferenciado. Assim também, o pensamento torna-se mais integrado quando progride para níveis superiores. $\mathrm{Na}$ terceira fase da pesquisa (terceiro ano de carreira), mostrou-se difícil separar a compreensão dos professores sobre ensino das de aprendizagem. Não foram encontradas regressões e nenhum professor permaneceu exatamente no mesmo nível de pensamento de uma entrevista para outra.

Se para Huberman (1995) e Cavaco (1995) as fases do processo de evolução profissional não são universais, Levin e Ammon (1992) parecem contrapor-se a essa idéia, quando sugerem que a ordem seqüencial das etapas é invariante, mas sem atentar para o aspecto contingencial das circunstâncias de vida individual e/ou histórico-sociais.

Não se pode contestar o fato de que as pressões e constrangimentos das condições de trabalho e dos contextos institucional, cultural e histórico deixam marcas nas trajetórias individuais ou no percurso do coletivo de docentes. Mas, deve-se questionar a ausência de um mecanismo regulador que possa controlar os "desvios de rota" presentes em cada uma das etapas descritas por Cavaco e Huberman. Para esses autores, o desenvolvimento profissional docente toma rumos individuais divergentes, mas não por força de qualquer explicação racional, pois não há indicações de que os professores pesquisados tenham sido submetidos a condições e circunstâncias opostas. Provavelmente, uma leitura piagetiana desse desenvolvimento daria maior coerência e consistência às interpretações de tais desvios que, na verdade, poderiam ser manifestações de níveis evolutivos distintos.

Piaget apresenta três construções teóricas que podem servir ao estudo da profissionalidade docente: a teoria de equilibração das estruturas cognitivas, na qual são particularmente relevantes as noções de abstração reflexiva, níveis de desenvolvimento e formas de reação compensatória a elementos perturbadores; a da tomada de consciência, em que se salientam as diferenças entre o fazer e o compreender, com seus mecanismos de regulação; e a do desenvolvimento do juízo moral.

Em obra clássica que descreve o processo de equilibração das estruturas de conhecimento, Piaget (1975) parte do postulado de que assimilação e acomodação constituem os componentes de todo equilíbrio cognitivo, responsáveis, portanto, pela conservação do sistema cognitivo. Enquanto o primeiro referese à incorporação de conteúdos às formas de organização presentes no sujeito, o segundo funciona de modo complementar, ajustando essas formas aos conteúdos que o meio oferece.

Assimilação e acomodação estariam presentes nas três formas de equilibração propostas por Piaget: entre sujeito e objeto; entre subsistemas de um sistema cognitivo; e entre estes subsistemas e a totalidade que os engloba. Desse modo, esquemas e estruturas de conhecimento tendem a se diferenciar continuamente para dar conta de objetos e situações diversos com que se depara o sujeito em sua atividade assimiladora, mas também podem se integrar em estruturas mais amplas, quando se coordenam entre si.

Esquemas e estruturas são organizadores da conduta e a ela subjacentes. Como tais, são inconscientes. Para se desenvolver, um esquema (ou estrutura) deve ser ativado; ele tem necessidade de "alimentos” para que funcione. Em situações de intercâmbio com o meio, o sujeito põe em funcionamento certo esquema, mas pode, a qualquer momento, deparar-se com novos objetos e situações que oferecem obstáculos à assimilação e provocam desajustes que precisam ser compensados para que haja reequilíbrio, que é sempre produzido em novas bases. Nesse caso, o esquema pode se diferenciar para melhor se ajustar à situação (acomodação), ou combinar com outros (assimilação recíproca) para dar conta do objeto ou situação inicialmente inassimilável.

Embora os desequilíbrios possam ser vistos como fonte de progresso, o seu papel, segundo Piaget (1975), é o de desencadear a busca de superação do estado atual a fim de atingir novos conhecimentos. A fonte real de progresso é, pois, constituída pela reequilibração, que significa não o retorno, mas o melhoramento da forma anterior. 
Desse modo, esquemas e estruturas são constantemente organizados e reorganizados durante o desenvolvimento da inteligência, num processo que tem a forma de períodos seqüenciais (Sensoriomotor, Operacional Concreto e Operacional Formal), que se sucedem sempre numa mesma ordem.

Para dar conta das perturbações que a realidade opõe ao equilíbrio atingido em certa etapa, o sujeito recorre a reações compensatórias, formas de reagir ao elemento perturbador de modo a compensar os seus efeitos e alcançar novamente o equilíbrio. Piaget (1975) propõe três formas de compensação, a primeira mais elementar e a última, mais avançada.

Na conduta chamada de tipo $\alpha$, diante de uma situação desestabilizante, o sujeito pode simplesmente tentar anulá-la introduzindo uma modificação na ação em sentido inverso daquele da perturbação, ou então, negar o fator perturbador, negligenciando-o ou afastando-o. Não se pode dizer que exista propriamente conflito aos olhos do sujeito, que acrescenta elementos que deformam de algum modo a situação para assimilá-la ao que é "normal”, familiar, comum.

Na conduta de tipo $\beta$, tenta-se integrar ao sistema o elemento perturbador, modificando-o por deslocamento de equilíbrio. Diante do problema ou obstáculo, o sujeito não mais busca anulá-lo, mas modificar o esquema disponível, de modo a ajustá-lo à situação em desequilíbrio.

Na conduta de tipo $\gamma$, por fim, o sujeito integrará o fator perturbador em seu sistema cognitivo e, nesse caso, podem ser antecipadas todas as variações possíveis, "as quais perdem, enquanto previsíveis e dedutíveis, seu caráter de perturbações e vêm se inserir nas transformações virtuais do sistema" (Piaget, 1975, p. 73).

Duas outras idéias de Piaget são igualmente importantes para a presente pesquisa: a distinção entre fazer (ou saber fazer) e compreender, e o papel da tomada de consciência. Piaget (1977) coloca que toda atividade humana exige algum grau de consciência, que se revela elementar ou periférica, na medida em que se aplica a dados imediatamente percebidos, aos objetivos da ação ou aos resultados constatados como êxito ou fracasso. Mas a consciência pode chegar à compreensão, quando recorre à tomada de consciência.
Na vida cotidiana, muitas vezes age-se sem que se esteja consciente. Os hábitos, de um modo geral, são ações que não requerem compreensão para que tenham êxito. Os reforços e correções eventuais são mais ou menos imediatos, o que dispensaria a necessidade de tomada de consciência para a eficiência da ação.

Esses exemplos de saber fazer são geralmente controlados por regulagens automáticas (determinadas de fora, sem escolha deliberada ou intencional do sujeito). Mas há ações que podem exigir a compreensão para terem êxito, o que torna necessária a tomada de consciência e a intervenção de regulagens ativas (em que o sujeito intervém deliberadamente no processo, com reforços ou correções da ação).

Assim, para Piaget (1977), a tomada de consciência procede da periferia da ação (objetivos e resultados percebidos como sucesso ou fracasso) e segue em direção aos seus mecanismos centrais. $\mathrm{O}$ ponto de partida seria, portanto, a busca de um objetivo, com a constatação consciente do êxito ou fracasso daí resultante. No fracasso, o sujeito trata de explicar por que ocorreu, com o dado de observação relativo ao objeto, ele procurará saber por que houve falha de adaptação do esquema ao objeto; e, frente à ação, ele focalizará sua atenção nos meios empregados e em suas correções ou substituições.

Com isso, nota-se que a noção piagetiana de conscientização não se confunde com a de uma espécie de "iluminação", pois não ocorre mecanicamente, nem tampouco de modo imediato. Existem graus de consciência, o que significa dizer graus de reflexão.

Por fim, em sua obra sobre o desenvolvimento do juízo moral na criança, Piaget (1994) apresenta estudos sobre a prática e a consciência da regra, no contexto do jogo coletivo. Sua análise das condutas infantis revela que a criança situa-se, inicialmente, numa fase de anomia, quando não é capaz de seguir regras coletivas e nem mesmo se interessa por elas. Numa segunda etapa, da heteronomia, ela já demonstra interesse em participar de um jogo em que as condutas devem seguir certas regras, mas concebendo-as como imutáveis e sagradas. Por fim, na etapa da autonomia, a criança joga segundo regras eleitas pelo grupo, vendo-as como fruto de acordos entre os jogadores. E qualquer jogador pode ser "legislador”, 
desde que as novas regras passem por apreciação e decisão coletivas.

As idéias acima, centrais na obra piagetiana, serviram de guias e fundamento do presente trabalho. Trata-se de uma investigação que tem adultos como participantes e não constitui um estudo sobre desenvolvimento cognitivo, mas profissional (embora o cognitivo seja imprescindível a ele), o que não torna impeditiva uma visão construtivista do tema.

A leitura feita da profissionalidade docente sob uma perspectiva construtivista concebe o professor como agente que constrói esquemas profissionais de natureza representativa, conceitual e/ou pragmática, na medida em que interage com um meio específico - o ambiente escolar; para que tais esquemas progridam e se aperfeiçoem, é fundamental a tomada de consciência, pelo professor, dos obstáculos enfrentados.

\section{Método}

A presente pesquisa destinou-se a investigar a possibilidade de níveis evolutivos na profissionalidade de professores de $1^{\mathrm{a}}$ a $4^{\mathrm{a}}$ séries (I Ciclo), tomando para estudo a prática pedagógica, a autonomia e a identidade profissional, tal como enunciadas em seus discursos, e também comparar os depoimentos desses professores com os apresentados por um grupo de professores de $5^{\mathrm{a}}$ a $8^{\mathrm{a}}$ séries (II Ciclo) de pesquisa anteriormente realizada (Chakur, 2001).

Partindo dos pressupostos acima e dos resultados obtidos com professores de $5^{\mathrm{a}}$ a $8^{\mathrm{a}}$ séries, foram levantados alguns problemas a serem tratados nesta pesquisa: os depoimentos dos professores de $1^{\mathrm{a}}$ a $4^{\mathrm{a}}$ séries (I Ciclo) poderiam ser dispostos em níveis, tais como os encontrados nos depoimentos de professores de $5^{\mathrm{a}}$ a $8^{\mathrm{a}}$ (II Ciclo)? Em caso positivo, seriam os mesmos os níveis de construção da profissionalidade nos dois grupos? Haveria alguma diferença significativa entre professores dos ciclos I e II a esse respeito?

Os participantes da pesquisa foram 14 professoras que davam aulas para turmas de $1^{\mathrm{a}}$ a $4^{\mathrm{a}}$ séries de uma escola estadual da cidade de Araraquara, SP, com idade variando de 27 a 59 anos, e tempo de serviço entre 8 e 23 anos.

Como instrumento de pesquisa, utilizaram-se oito histórias simulando situações reais do cotidiano escolar, cada qual apresentando um problema ou con- flito vivido por um professor; a seguir reproduzemse, com as modificações pertinentes, as histórias, tal como constam em Chakur (2001).

A primeira, denominada Indisciplina, focaliza a prática pedagógica e volta-se mais propriamente para a função do professor de gestão de classe (Gauthier, 1998). Apresenta uma situação em que uma professora deveria tomar uma atitude diante de um aluno de $1^{\text {a }}$ série que, segundo ela, fazia "muita bagunça”. Após pedir avaliação do comportamento do aluno, era perguntado que atitude seria essa e, ao final, a entrevistada deveria imaginar a atitude do professor caso a classe fosse de $4^{a}$ série.

A segunda, denominada Rendimento, também focaliza a prática pedagógica, mas agora tendo em vista a função docente de ensino dos conteúdos (Gauthier, 1998). Conta que 50\% de uma classe de $2^{\text {a }}$ série com 40 alunos apresentou rendimento abaixo da média, segundo avaliação realizada pela professora no início do ano; aí era solicitado que a entrevistada explicasse esse fracasso dos alunos e sugerisse como a professora deveria agir com os "fracos" e o que fazer com a matéria programada para aquela série e com o livro didático já adotado. Perguntava-se, ainda, o que a professora deveria fazer se uns dez alunos continuassem sem acompanhar a matéria, apesar das intervenções anteriores.

A história de número 3, Motivação, focalizando a prática pedagógica em geral, aborda o problema de um professor com três alunos de $4^{\text {a }}$ série, que eram muito unidos, sentavam-se próximos uns dos outros e não conseguiam prestar atenção na aula de (disciplina escolhida pela entrevistada). Além de solicitar que a entrevistada imaginasse o motivo da falta de atenção dos alunos, pedia-se que sugerisse formas de superá-la. A última questão era repetida para o caso de alunos da $2^{\text {a }}$ série.

Merenda é como se chama a quarta história, destinada a avaliar a identidade profissional docente, ao abordar o problema de uma escola cuja merenda era irregular, resultando que, muitas vezes, os alunos assistiam às aulas com fome. Uma professora tentava suprir a falta de merenda trazendo lanche de casa para seus alunos. Perguntava-se, então, como a entrevistada explicaria a situação da escola e dos alunos, se a professora agia bem trazendo o lanche para as crianças e o que mais poderia fazer. Ao 


\section{Cilene Ribeiro de Sá Leite Chakur}

final, supondo que, não a merenda, mas a merendeira faltava, perguntava-se o que a professora da história poderia fazer nesse caso e como a entrevistada via o fato de a professora fazer a merenda.

A quinta história, chamada Rotina pedagógi$c a$, volta-se, novamente, para a prática pedagógica em sua faceta de ensino dos conteúdos. Trata-se de uma professora que lecionava com êxito para $4^{\mathrm{a}}$ série, sempre de uma mesma maneira, mas ao tentar repetir o procedimento com uma classe de $2^{\mathrm{a}}$ série, percebeu que não obtinha sucesso: os alunos tinham condutas inadequadas e não compreendiam a matéria. Além de questões sobre os alunos (por que apresentavam condutas inadequadas e não conseguiam compreender a matéria), sobre o procedimento, e a decisão da professora, pediam-se sugestões para eliminar as condutas inadequadas dos alunos e fazê-los compreender a matéria.

As três histórias seguintes tratam de conflitos interpessoais - entre professora e alunos, professora e diretora da escola, entre colegas. As duas primeiras tentam avaliar, em especial, a autonomia docente, enquanto a última focaliza a identidade profissional.

Na situação Conflito professor-alunos, a sexta na ordem de aplicação, contava-se uma história em que uma professora experiente e bem preparada lecionava para uma turma de $4^{\mathrm{a}}$ série bastante questionadora e ativa, o que a incomodava. Numa aula mais quente, de revisão da matéria, decidiu que era a sua vez de perguntar, resolvendo fazer uma chamada oral para nota, mas os alunos recusaram-se a atendê-la, alegando que não haviam sido avisados com antecedência. Pedia-se, em seguida, que a entrevistada avaliasse a situação, explicasse as condutas dos alunos e da professora, julgasse quem tinha razão na história e sugerisse formas de solução para o impasse, sempre solicitando justificativas.

A história Conflito entre colegas conta que seis alunos de uma turma de $3^{\text {a }}$ série não pareciam alfabetizados, pois não mostravam aprendizagem nas aulas de Português. A professora queixou-se com a colega que dera aula para a classe no ano anterior, alegando necessidade de reforço para aqueles alunos, enquanto a colega argumentava que o problema era da professora atual. Pedia-se explicação sobre o problema, perguntava-se qual das professoras tinha razão em "cobrar" da outra e, a seguir, quem teria razão se uma das professoras fosse substituta temporária, e, ao final, eram solicitadas sugestões.

Na história Conflito professor-diretor, a última da série, dizia-se que certa professora, que lecionava para uma turma bastante aplicada e interessada, gostava de propor atividades diferentes, com jogos, música e discussões, o que gerava certo barulho e deixava a sala desorganizada para a próxima aula, mas eram atividades sempre produtivas. Após várias reclamações que não surtiram efeito, a diretora resolveu proibir a professora de dar aquele tipo de aula. Em seguida, eram feitas perguntas relativas à conduta dos alunos (agitação) e da professora (insistência) e sobre quem teria razão, professora ou diretora, e, ao final se ao invés da diretora fosse uma colega a reclamar, de quem seria a razão.

Em algumas histórias, solicitava-se que a entrevistada imaginasse a decisão que o personagemprofessor deveria tomar a respeito do problema colocado; em outras, apenas julgasse a atitude do personagem. Mas, em todas elas, pediam-se explicações acerca de condutas dos personagens e soluções possíveis para o problema ou conflito e em todas as histórias, começava-se o interrogatório solicitando uma avaliação geral da situação.

O procedimento foi o mesmo empregado com os professores do II Ciclo: o instrumento aplicado individualmente, em cada professora da amostra, sempre na mesma ordem. Utilizou-se a entrevista informal, seguindo o método de exploração crítica piagetiano (Domahidy-Dami \& Banks Leite, 1987; Piaget, 1929); desse modo, no desenrolar da entrevista, buscava-se acompanhar o raciocínio da informante e desencadear novos questionamentos, nem sempre previstos de antemão, partindo das representações e julgamentos que ela fazia a respeito da situação e dos argumentos que apresentava para justificar suas respostas. Empregava-se, também, a contra-argumentação para atestar a segurança e a coerência das respostas obtidas.

Tal como observado no grupo de $5^{\mathrm{a}}$ a $8^{\mathrm{a}}$ séries, durante as entrevistas, a professora entrevistada sempre se identificava com o personagem principal da história, o que a fazia responder às perguntas geralmente na primeira pessoa.

$\mathrm{Na}$ análise dos dados, foram empregados os critérios e procedimentos utilizados com professores 
do II Ciclo. Primeiramente, recorreu-se à análise qualitativa dos depoimentos, um por um, estabelecendo certas categorias, segundo critérios empíricos combinados com outros de caráter teórico, sugeridos em obras piagetianas. Foram relevantes os critérios de centração/descentração (com relação a personagens, aspectos de comportamento, resultado constatado), aparência/imediatismo (na percepção de traços ou características levantadas) e seus opostos, flexibilidade da prática, assimilação da função docente e responsabilidade profissional, tomados em seus vários graus, além da qualidade argumentativa presente nos depoimentos. Em seguida, buscou-se seqüenciar tais categorias em níveis distintos. $\mathrm{Na}$ análise das atitudes das professoras diante dos conflitos, tomou-se como critérios as três formas de reações compensatórias propostas por Piaget (1975).

\section{Resultados \\ O desenvolvimento da profissionalidade de professores de $1^{\text {a }}$ a $4^{\text {a }}$ séries}

Os depoimentos das professoras do I Ciclo pouco se afastam dos obtidos com seus colegas de II Ciclo em pesquisa anterior (Chakur, 2001). Tal como observado nestes últimos, a prática pedagógica, a autonomia de trabalho e a identidade profissional se desenvolvem numa série hierárquica de níveis progressivamente mais aperfeiçoados. Os níveis de construção da profissionalidade docente, que reúne os três eixos acima, servem para definir o desenvolvimento profissional de professores de ambos os ciclos $-1^{\mathrm{a}}$ a $4^{\mathrm{a}}$ e $5^{\mathrm{a}}$ a $8^{\mathrm{a}}$ séries do Ensino Fundamental.

Nível I. Profissionalidade fragmentada, com desvio de identidade - Os traços básicos neste caso são a prática reiterativa automatizada, a heteronomia e o desvio de identidade. A prática pedagógica toma a forma de rotinas cristalizadas. É automatizada e resistente à mudança e os mesmos esquemas de atuação são aplicados a situações, classes de alunos e contextos diferentes.

As soluções para lidar com os problemas em classe (condutas tidas como inadequadas, falhas de compreensão do aluno) são predominantemente heterônomas, repressivas e descomprometidas com a aprendizagem, ou revelam-se medidas reiterativas/ remediativas (repetir, reforçar o conteúdo). A heteronomia, na verdade, é geral, aparecendo como submissão aos constrangimentos da situação e às pressões da hierarquia presente no sistema escolar.

A identidade profissional mostra-se fragmentada e sem fronteiras definidas. A fragmentação e confusão da identidade profissional estão presentes na aceitação ou conivência com desvios de função, no baixo grau de consciência do papel profissional e na negação ou omissão de responsabilidade (pelo próprio desempenho ou por problemas apresentados pelos alunos).

A reação a conflitos se faz pela negação ou afastamento e, às vezes, o professor reage à situação de conflito negando, retirando o elemento perturbador, ou mesmo deformando-o, para assegurar a harmonia. A tendência é ceder à pressão exterior ou insistir no confronto com base na "razão da autoridade”. As reações a conflitos interpessoais, bem como as tentativas de solução, neste nível, são fundadas no dever heterônomo (Piaget, 1994) e apóiam-se em esquemas mentais familiares (Boder, 1996; Inhelder \& De Caprona, 1996) que "traduzem" a situação para o professor e determinam o que ele consegue realmente perceber numa situação de conflito.

Desse modo, o professor mostra uma consciência apenas elementar ou periférica, neste primeiro nível, e a abstração reflexiva manifesta-se como simples representação da situação problemática, com ausência de ligações, apenas parciais, ou mecânicas, entre os observáveis constatados.

Nível II. Profissionalidade localizada, com semi-identidade - que apresenta como traços principais a mobilidade pontual da prática, a semiautonomia e a semi-identidade profissional, podendo revelar nuances, ou sub-níveis (A e B, no caso). Na prática pedagógica deste nível, a flexibilidade nascente toma a forma de uma busca cega de alternativas às práticas tradicionais; ela se apoia em centrações alternadas em diferentes elementos presentes na situação e em análises pontuais, ou muito genéricas, das situações problemáticas, o que resulta em julgamentos e decisões muitas vezes ambíguos.

Nas soluções, mantêm-se as medidas repressivas e as reiterativas/remediativas, juntamente com outras não repressivas (como conversar com o aluno), mas predominam soluções acomodadoras, em 


\section{Cilene Ribeiro de Sá Leite Chakur}

que há tentativas de adequar o ensino às condições do aprendiz. Ao lado destas, há duas categorias de soluções próprias desse nível e que sinalizam um grau mais adiantado de reflexão sobre a prática (nível IIB): nas medidas investigativas, o professor sai em busca de informações, de razões e fatores não imediatamente aparentes para a compreensão do problema e a tomada de decisão; e nas soluções de compromisso, o esquema interpretativo de que o professor dispõe no momento sofre modificações para que possa ajustar-se à situação. Embora consistindo em forma incompleta de compensação do elemento perturbador, os compromissos assinalam um início de tomada de conhecimento e de consciência. Os esquemas familiares começam, então, a descristalizar-se (Boder, 1996) em função da introdução de regulagens ativas.

O início de descentração é também observável em situação de conflito interpessoal, que é considerado, mas aparecem centrações alternadas em elementos ou fatores distintos percebidos na situação. É o caso das tentativas do professor de justificar, de modo forçado e rudimentar, as ações e atitudes de um e de outro dos protagonistas envolvidos no conflito.

A autonomia que se inicia mostra-se em atitudes tanto de respeito aos direitos dos alunos, em contraposição ao exercício da autoridade de modo arbitrário (quando utiliza instrumentos pedagógicos com fins punitivos, por exemplo), quanto de respeito ao colega, ou ao diretor, se a classe manifesta-se barulhenta.

Os traços de fragmentação/confusão de identidade profissional, vistos anteriormente, tornam-se mais fracos. É comum o questionamento dos desvios de função, cuja ocorrência o próprio professor condiciona a situações extremadas (nível IIB). Mas algumas soluções mostram, ainda, compromissos que evitam definições precisas da atividade profissional docente.

Nível III. Profissionalidade refletida - apresenta como traços básicos o exercício profissional refletido, a autonomia responsável e a identidade profissional. Este nível também se caracteriza pela flexibilidade da prática, como o anterior, mas revela outra natureza: a matéria programada submetese ao ritmo de aprendizagem e às peculiaridades dos alunos só após análise da situação; a experimentação de materiais didáticos ocorre de maneira criteriosa; os procedimentos são alterados em função de dados analisados e de justificativas bem fundamentadas. A rigidez, os automatismos, as ambigüidades e experimentações cegas estão ausentes.

Assim também, não se notam soluções heterônomas no tratamento dos problemas. Às investigativas, que permanecem, junta-se a busca de alternativas inovadoras, sem que o professor deixe de atentar para as particularidades de comportamento dos alunos e para as razões que as explicam.

Todos esses traços significam, ao mesmo tempo, descentração de perspectiva e alargamento do referencial de análise e interpretação. Estão presentes tanto a tomada de consciência da própria ação, facilitada pelo concurso de regulagens ativas, que permitem o exercício refletido da prática, como a compreensão da conduta do aluno. As decisões são, desse modo, baseadas na reflexão e pode-se afirmar que a profissionalidade refletida segue os princípios do dever autônomo descrito por Piaget (1994).

O conflito interpessoal, por sua vez, é assimilado a uma visão integrada da situação, na qual se salientam não apenas o direito do outro, como também o direito e a legitimidade da ação docente em seu sentido profissional.

Quanto à identidade profissional, desaparecem os traços de confusão ou fragmentação e o professor não aceita desvio de função. Do sentimento de pertença a uma categoria profissional resultam relações cooperativas e a consciência de responsabilidade conjunta pela função docente, percebida como comum, pertencente a um corpo coeso de profissionais do ensino.

\section{Comparando professores dos ciclos I e II}

Assim caracterizados os níveis de desenvolvimento profissional, fez-se a contagem de freqüência de depoimentos de cada nível nos âmbitos da prática pedagógica, autonomia e identidade profissional, separadamente. Para fins de comparação, retomamse os dados dos professores de $5^{\mathrm{a}}$ a $8^{\mathrm{a}}$ séries da pesquisa anterior, aqui identificados também como do II Ciclo, enquanto os de $1^{\text {a a }} 4^{\text {a }}$ são de I Ciclo.

A amostra de $5^{\mathrm{a}}$ a $8^{\mathrm{a}}$ séries contou com 19 professores, com idade variando de 23 a 47 anos e com tempo de serviço de 3 a 20 anos. 
As Tabelas 1, 2 e 3 trazem os dados - em freqüências absoluta e porcentagem, dos dois grupos, sobre a prática pedagógica, autonomia e identidade profissional.

Tabela 1. Freqüência dos níveis de desenvolvimento da prática pedagógica entre professores dos Ciclos I e II

\begin{tabular}{|c|c|c|c|c|c|}
\hline Nível & I & IIA & IIB & III & Total \\
Ciclo & & & & & \\
\hline I & $0(0)$ & $6(42,9)$ & $5(35,7)$ & $3(21,4)$ & $14(100)$ \\
\hline II & $2(10,5)$ & $5(26,3)$ & $11(57,9)$ & $1(5,3)$ & $19(100)$ \\
\hline
\end{tabular}

Tabela 2. Freqüência dos níveis de desenvolvimento da autonomia docente entre professores dos Ciclos I e II

\begin{tabular}{|c|c|c|c|c|c|}
\hline $\begin{array}{c}\text { Nivel } \\
\text { Ciclo }\end{array}$ & I & IIA & IIB & III & Total \\
\hline I & $0(0)$ & $3(21,4)$ & $8(57,1)$ & $3(21,4)$ & $14(100)$ \\
\hline II & $3(15,8)$ & $4(21,1)$ & $11(57,9)$ & $1(5,3)$ & $19(100)$ \\
\hline
\end{tabular}

Tabela 3. Freqüência dos níveis de desenvolvimento da identidade profissional docente entre professores dos Ciclos I e II

\begin{tabular}{|c|c|c|c|c|c|}
\hline $\begin{array}{c}\text { Nivel } \\
\text { Ciclo }\end{array}$ & I & IIA & IIB & III & Total \\
\hline I & $0(0)$ & $3(21,4)$ & $8(57,1)$ & $3(21,4)$ & $14(100)$ \\
\hline II & $1(5,3)$ & $4(21,1)$ & $12(63,2)$ & $2(10,5)$ & $19(100)$ \\
\hline
\end{tabular}

Pode-se notar, nas tabelas acima, que nenhuma das professoras do I Ciclo situa-se no nível I, seja da prática, da autonomia ou da identidade profissional, diferentemente do grupo do II Ciclo, que apresenta um ou mais professores nesse nível, nos três âmbitos. No nível III, por sua vez, há sempre maior freqüência de professores do I Ciclo que do II Ciclo. À primeira vista, portanto, as professoras de $1^{\mathrm{a}} \mathrm{a} 4^{\mathrm{a}}$ séries parecem ter apresentado melhor desempenho que seus colegas de $5^{\mathrm{a}}$ a $8^{\mathrm{a}}$.

Na prática pedagógica, embora seja nula a freqüência do nível I entre professores de $1^{\mathrm{a}}$ a $4^{\mathrm{a}}$, o predominante é o que se lhe segue imediatamente (nível IIA), com 42,9\% de casos; e apesar de alguns professores de $5^{\mathrm{a}}$ a $8^{\mathrm{a}}$ se situarem no nível I, predomina entre eles o IIB, com 57,9\% dos casos. Mas não se pode negar que a proporção dos que chegaram ao nível III é bem maior no grupo de $1^{\mathrm{a}}$ a $4^{\mathrm{a}}$
(21,4\%) que no de $5^{\mathrm{a}}$ a $8^{\mathrm{a}}$ séries $(5,3 \%)$. Estas diferenças precisariam ser melhor atestadas com um número maior de sujeitos por amostra.

No que se refere à autonomia profissional, os dados se mostram um pouco mais definidos. Em ambos os grupos predomina o nível IIB, mas há maior freqüência do I entre professores de $5^{\mathrm{a}}$ a $8^{\mathrm{a}}$ séries e maior freqüência do III entre os de $1^{\text {a a }} 4^{\text {a }}$.

Quanto à identidade profissional, enfim, novamente o nível IIB é o que predomina nos dois grupos e não parece haver grandes diferenças entre ambos nos demais níveis.

Como já mencionado, caberia ampliar o número de participantes de cada grupo para poder ter uma visão mais precisa das possíveis diferenças na construção da profissionalidade dos professores dos dois ciclos. Mas, algumas hipóteses acerca da aparente superioridade nos níveis de aquisição da profissionalidade das professoras do I Ciclo, especialmente no que se refere à prática pedagógica e à autonomia, relativamente ao observado em professores do II Ciclo, podem ser levantadas.

É possível que as diferenças observadas estejam refletindo um maior envolvimento e compromisso das professoras do I Ciclo com as suas classes e com a escola em que trabalham. Talvez, a situação com que convivem essas professoras possibilite, por exemplo, maior interação com as crianças, resultando em maior responsabilidade e poder de decisão para com a classe, já que não dão aulas em muitas classes como o fazem os do II Ciclo.

Assim também, o fato de os professores do I Ciclo lecionarem em poucas escolas permite o aparecimento de sentimentos de pertença e compromisso com o local de trabalho, o que certamente é mais difícil no caso dos do II Ciclo, que necessitam completar a jornada lecionando em várias escolas (Dias da Silva \& Chakur, 1990). A isso se acrescenta o fato de que os de $5^{\text {a }}$ a $8^{\text {a }}$ séries, sendo especialistas em determinadas disciplinas curriculares, sentirem maior dificuldade em entrar em diálogo com colegas de outras áreas de conhecimento e, em conseqüência, em manter com estes trocas de idéias e experiências.

Esses são traços de diferentes situações de trabalho que podem resultar, também, em maior ou menor aproximação e estabelecimento de laços entre os professores e destes com a escola em que leci- 
onam, possibilitando trocas de informações e experiências e trabalho cooperativo mais freqüentes entre os do I Ciclo do que o observado entre os do II Ciclo.

Tudo isso pode favorecer o desenvolvimento profissional dos professores, que requer, evidentemente, um ambiente "profissionalmente saudável" para que os "desequilíbrios" sejam superados de modo construtivo.

\section{Considerações finais}

Pode-se afirmar que os objetivos da pesquisa foram alcançados satisfatoriamente. A análise qualitativa mostrou que o desenvolvimento profissional de professoras de $1^{\text {a a }} 4^{\text {a }}$ séries, tomado em seus três eixos (prática pedagógica, autonomia e identidade profissional), ocorre numa seqüência de níveis hierárquicos, caracterizados por um aperfeiçoamento progressivo, de modo semelhante ao encontrado entre os professores de $5^{\mathrm{a}}$ a $8^{\mathrm{a}}$ séries.

Verificou-se que os depoimentos dos professores dos dois ciclos se distribuíram em três níveis gerais, chamados de construção da profissionalidade docente, cada qual se configurando, na seqüência, como um patamar "mais equilibrado" em relação ao anterior.

Mas é necessário salientar que essa seqüência difere em muito das apresentadas por outros autores (Berliner, 1988; Cavaco, 1995; Huberman, 1995; e Lidstone \& Hollingsworth, 1992). Na verdade, o trajeto encontrado parece anunciar um processo equilibrador responsável pela regulação do pensamento e da ação dos professores, sendo que os níveis estabelecidos não comportam, meramente, estilos de aprender a ensinar. Mas, seguramente, os avanços notados quando se passa de um a outro nível evolutivo têm muito a ver com a tomada de consciência do professor, tendo esta por objetos, entre outras coisas, a própria prática, a visão e a atitude docentes para com os alunos, o envolvimento do professor com as questões do ensino e a responsabilidade que sentem pela aprendizagem dos alunos e pela própria atuação.

\section{Referências Bibliográficas}

Berliner, D. C. (1988). Implications of studies of expertise in Pedagogy for teacher education and evaluation. New Directions for Teacher Assessment, Proceedings of the 1988 ETS
Invitational Conference, Princeton, New Jersey: Educational Testing Service (pp. 39-67).

Boder, A. (1996). 'Esquema familiar’: a unidade cognitiva de procedimento preferida. Em B. Inhelder \& G. Cellérier, O desenrolar das descobertas da criança: um estudo sobre as microgêneses cognitivas (pp. 186-211). Porto Alegre: Artes Médicas.

Cavaco, M. H. (1995). Ofício do professor: o tempo e as mudanças. Em A. Nóvoa, (Org.). Profissão professor (pp.155-191). Porto: Porto Editora.

Chakur, C. R. de S. L. (2001). Desenvolvimento profissional docente: contribuições de uma leitura piagetiana. Araraquara: JM.

Contreras, J. (2002). A autonomia de professores. São Paulo: Cortez.

Dias da Silva, M. H. G. F. \& Chakur, C. R. de S. L. (1990). O ensino de $5^{a}$ a $8^{a}$ séries: pistas para a compreensão da escola pública. Boletim do Departamento de Didática. Araraquara: Faculdade de Ciências e Letras - UNESP, 6, 29-40.

Domahidy-Dami, C. \& Banks Leite, L. (1987). As provas operatórias no exame das funções cognitivas. Em L. Banks Leite, (Org.). Piaget e a Escola de Genebra. (pp. 111-123). São Paulo: Cortez.

Furth, H. G. (1980). The world of grown-ups: Childrens' conceptions of society. New York: Elsevier.

Gauthier, C. (1998). Por uma teoria da pedagogia: pesquisas contemporâneas sobre o saber docente. Ijuí: Unijuí.

Giovanni, L. M. (1994). A didática da pesquisaação: análise de uma experiência de parceria entre universidade e escolas públicas de $1^{\circ} e$ $2^{\circ}$ graus. Tese de Doutorado, Universidade de São Paulo, São Paulo.

Huberman, M. (1995). O ciclo de vida profissional dos professores. Em A. Nóvoa, (Org.). Vidas de professores (pp. 31-61). Porto: Porto Editora. 
Imbernón, F. (1994). La formación y el desarrollo profesional del profesorado: hacia una nueva cultura profesional. Barcelona: Graó.

Inhelder, B. \& De Caprona, D. (1996). Rumo ao construtivismo psicológico: Estruturas? Procedimentos? Os dois ‘indissociáveis’. Em B. Inhelder, \& G. Cellérier, (Orgs.). O desenrolar das descobertas da criança: um estudo sobre as microgêneses cognitivas (pp.7-34). Porto Alegre: Artes Médicas.

Levin, B. B. \& Ammon, P. (1992). The development of beginning teachers'pedagogical thinking: a longitudinal analysis of four case studies. Teacher Education Quarterly, 19 (4), 19-37.

Lidstone, M. L. \& Hollingsworth, S. (1992). A longitudinal study of cognitive change in beginning teachers: Two patterns of learning to teach. Teacher Education Quarterly, 19 (4), 39-57.

Marcelo García, C. (1992). A formação de professores: novas perspectivas baseadas na investigação sobre o pensamento do professor. Em A. Nóvoa, (Org.). Os professores e a sua formação (pp.51-76). Lisboa: Dom Quixote.

Marin, A. J. (2000). Desenvolvimento profissional docente e transformações na escola. Relatório de Pesquisa. Universidade Estadual Paulista, Faculdade de Ciências e Letras/FAPESP, Araraquara.

Nóvoa, A. (1992). Formação de professores e profissão docente. Em A. Nóvoa, (Org.). Os professores e a sua formação (pp.13-33). Lisboa: Dom Quixote.

Nóvoa, A. (1994). Les enseignants: à la recherche de leur profession. European Journal of Teacher Education, 17 (1/2), 35-43.

Nóvoa, A. (1995). O passado e o presente dos professores. Em A. Nóvoa, (Org.). Profissão professor. (pp. 13-34). Porto: Porto Editora.

Pérez Gómez, A. I. (1992). O pensamento prático do professor. A formação do professor como profissional reflexivo. Em A. Nóvoa, (Org.) Os professores e a sua formação. (pp. 93-114). Lisboa: Dom Quixote.
Piaget, J. (1929). A representação do mundo na criança. Rio de Janeiro: Record.

Piaget, J. (1975). L'équilibration des structures cognitives: problème central du développement. Paris: PUF.

Piaget, J. (1977). A tomada de consciência. São Paulo: Melhoramentos.

Piaget, J. (1994). O juízo moral na criança. São Paulo: Summus.

Shavelson, R. J. \& Stern, P. (1981). Research on teachers' pedagogical thoughts, judgments, decisions and behavior. Review of Educational Research, 51 (4), 455-498.

Schön, D. A. (1992a). Formar professores como profissionais reflexivos. Em A. Nóvoa, (Org.) Os professores e a sua formação (pp. 77-91). Lisboa: Dom Quixote.

Schön, D. A. (1992b). La formación de profesionales reflexivos: hacia un nuevo diseño de la enseñanza y el aprendizaje en las profesiones. Barcelona: Paidós.

Zabalza, M. A. (1994). Diários de aula (contributo para o estudo dos dilemas práticos dos professores). Porto: Porto Editora.

Zeichner, K. M. (1992). Novos caminhos para o practicum: uma perspectiva para os anos 90 . Em A. Nóvoa, (Org.). Os professores e a sua formação. (pp. 115-138). Lisboa: Dom Quixote.

Zeichner, K. M. (1993) A formação reflexiva de professores: idéias e práticas. Lisboa: Educa.

Obs.: Trabalho apresentado na XXXIII Reunião Anual de Psicologia da Sociedade Brasileira de Psicologia, realizada em Belo Horizonte - MG, em 2003. 